\title{
Pengaruh Tax Planning Dan Leverage Terhadap Nilai Perusahaan Dengan Transparansi Perusahaan Sebagai Variabel Moderasi
}

(Studi Empiris pada Perusahaan Properti dan Real Estate yang Terdaftar di Bursa Efek Indonesia Tahun 2016-2020)

\author{
Lusiyana Ika Pratiwi ${ }^{1}$, Hari Stiawan ${ }^{2}$ \\ 1,2Program Studi Akuntansi, Fakultas Ekonomi dan Bisnis, Universitas Pamulang, Tangerang \\ selatan, Indonesia \\ Email: ${ }^{1}$ lusiyana.ikapratiwi@gmail.com, ${ }^{2}$ dosen01254@unpam.ac.id
}

\begin{abstract}
The aims of the study are to examine and analyze the effect of tax planning and leverage on firm value with corporate transparency as a moderating variable. The type of research used in this study is a type of quantitative research. The data source used is secondary data, namely the annual report obtained from the Indonesia Stock Exchange (IDX). The population used in this study are property and real estate companies listed on the Indonesia Stock Exchange (IDX) during the 2016-2020 period. The sample selection technique used purposive sampling technique and obtained as many as 12 companies for 5 years with a total sample data obtained was 60 sample data. The results of this study indicate that the tax planning variable has an effect on the firm value variable, the leverage variable has no effect on the firm value variable, the tax planning variable and leverage simultaneously affect the firm value, the corporate transparency variable is able to moderate by strengthening the effect of the tax planning variable on the firm value. company and the company's transparency variable can be moderated by strengthening the relationship between leverage and firm value.
\end{abstract}

Keywords: Tax Planning, Leverage, Firn Value, Corporate Transparency.

\begin{abstract}
Abstrak
Penelitian ini bertujuan untuk menganalisis pengaruh tax planning dan leverage terhadap nilai perusahaan dengan transparansi perusahaan sebagai variabel moderasi. Jenis penelitian yang digunakan dalam penelitian ini adalah jenis penelitian kuantitatif. Sumber data yang digunakan adalah data sekunder yaitu laporan tahunan yang diperoleh dari Bursa Efek Indonesia (BEI). Populasi yang digunakan dalam penelitian ini adalah perusahaan properti dan real estate yang terdaftar di Bursa Efek Indonesia (BEI) selama periode 2016-2020. Teknik pemilihan sampel menggunakan teknik purposive sampling dan diperoleh sebanyak 12 perusahaan selama 5 tahun dengan total data sampel yang didapatkan adalah 60 data sampel. Hasil dari penelitian ini dengan menunjukkan bahwa variabel tax planning berpengaruh terhadap variabel nilai perusahaan, variabel leverage tidak berpengaruh terhadap variabel nilai perusahaan, variabel tax planning dan leverage berpengaruh secara simultan terhadap nilai perusahaan, variabel transparansi perusahaan mampu memoderasi dengan memperkuat pengaruh variabel tax planning terhadap nilai perusahaan dan variabel transparansi perusahaan dapat memoderasi dengan memperkuat antara hubungan leverage terhadap nilai perusahaan.
\end{abstract}

Kata Kunci: Tax Planning, Leverage, Nilai Perusahaan, Transparansi Perusahaan.

\section{PENDAHULUAN}

Persaingan pesat antara perusahaan telah mewarnai era globalisasi saat ini, setiap perusahaan akan berusaha semaksimal mungkin untuk mencapai tujuan yaitu meningkatkan nilai perusahaan. Ada beberapa faktor yang mempengaruhi nilai perusahaan, yaitu: indeks harga 
saham, keputusan pendanaan, kebijakan dividen, keputusan investasi, struktur modal, pertumbuhan perusahaan, ukuran perusahaan, dan kondisi fundamental perusahaan.

Adapun kasus yang berkaitan dengan nilai perusahaan yaitu Nilai pasar Lippo Group menurun sebesar 1,43 triliun selama sepekan setelah KPK menangkap salah satu petinggi proyek Meikarta. Sebanyak sembilan dari total 15 emiten Lippo Group yang sahamnya tercatat di BEI mengalami penurunan. Penurunan saham terbesar dialami oleh PT Lippo Cikarang Tbk. (LPCK) sebesar 20\%, diikuti PT Multipolar Technology Tbk. (MLPT) 15\%, dan PT Star Pacific Tbk. (LPLI) sebesar 12\%. Karena harga saham mengalami penurunan, maka membuat nilai pasar per emiten juga turun pada periode yang sama. Penurunan terbesar dialami oleh anak grup Lippo yaitu PT Matahari Department Store Tbk. (LPPF) sebesar Rp 961 miliar, diikuti PT Lippo Karawaci Tbk. (LPKR) sebesar Rp 470 miliar, dan PT Multipolar Technology Tbk. (MLPT) sebesar Rp 221 miliar [2].

Hal yang mempengaruhi nilai perusahaan salah satu nya keputusan dari manajemen yaitu dengan melakukan tax planning. Tax Planning merupakan salah satu upaya dari wajib pajak untuk meminimalkan pajak terhutang melalui skema yang sudah diatur dalam peraturan Undang-undang Perpajakan dan tidak menunjukan perselisihan (Dispute) antara wajib pajak dengan Otoritas pajak (Darussalam, 2009 dalam putri, 2015). Hal tersebut dapat dilakukan dengan memanfaatkan peraturan yang ada untuk memperoleh peningkatan laba setelah pajak yang akan berdampak pada peningkatan nilai perusahaan. Dari sisi perusahaan sendiri pajak menjadi hal yang sangat berpengaruh bagi kelangsungan hidup perusahaan.

Leverage merupakan gambaran atas pemakaian hutang suatu perusahaan untuk membiayai kegiatan operasional perusahaan. Pengelolaan leverage sangatlah penting, sebab keputusan dalam penggunaan hutang yang tinggi dapat meningkatkan nilai perusahaan yang dikarenakan adanya pengurangan atas pajak penghasilan. Perusahaan yang menggunakan leverage dengan tujuan agar keuntungan yang diperoleh lebih besar dari biaya tetap (beban tetap). Ada hal lain yang mempengaruhi nilai perusahaan yaitu transparansi perusahaan yang penulis jadikan sebagai variabel moderasi. Transparansi perusahaan sering diartikan sebagai keterbukaan informasi, baik itu dalam proses pengambilan keputusan maupun dalam mengungkapkan informasi material yang relevan mengenai perusahaan. Transparansi dapat meningkatkan ketepatan informasi publik yang tersedia untuk investasi, dan untuk keputusan manajemen. Sehingga dengan meningkatkan tingkat transparansi dari laporan tahunan perusahaan yang akan diberikan kepada investor, seharusnya dapat meredam dampak buruk yang akan dirasakan oleh perusahaan atas keputusan investasi dari investor.

Berdasarkan fenomena pada latar belakang diatas, terlihat bahwa hasil penelitian mengenai pengaruh tax planning terhadap nilai perusahaan, pengaruh leverage terhadap nilai perusahaan dan juga pengaruh transparansi perusahaan terhadap nilai perusahaan juga masih memberikan hasil yang ketidak konsistenan dari hasil penelitian sebelumnya, oleh karena itu peneliti tertarik untuk melakukan penelitian yang berjudul "Pengaruh Tax Planning Dan Leverage Terhadap Nilai Perusahaan Dengan Transparansi Perusahaan Sebagai Variabel Moderasi (Studi Empiris Pada Perusahaan Properti dan Real Estate yang Terdaftar Di BEI Periode 2016-2020)".

\section{Rumusan Masalah}

Berdasarkan latar belakang diatas, maka rumusan permasalahan yang hendak diteliti dalam penelitian ini adalah sebagi berikut :

1. Apakah tax planning berpengaruh terhadap nilai perusahaan?

2. Apakah leverage berpengaruh terhadap nilai perusahaan?

3. Apakah tax planning dan leverage berpengaruh terhadap nilai perusahaan?

4. Apakah transparansi perusahaan memoderasi pengaruh tax planning terhadap nilai perusahaan?

5. Apakah transparansi perusahaan memoderasi pengaruh leverage terhadap nilai perusahaan?

\section{METODE PENELITIAN}

Dalam penelitian ini menggunakan metode kuantitatif dengan pendekatan penelitian deskriptif. Data sekunder digunakan dalam penelitian ini agar data dapat dihitung untuk menghasilkan penaksiran kuantitatif yang kokoh. Dalam penelitian ini analisis deskriftif digunakan untuk 
mengetahui bagaimana pengaruh tax planning, leverage terhadap nilai perusahaan dengan transparansi perusahaan sebagai variabel moderasi pada perusahaan property dan real estate yang terdaftar di Bursa Efek Indonesia periode 2016-2020.

Tabel 1. Indikator Variabel

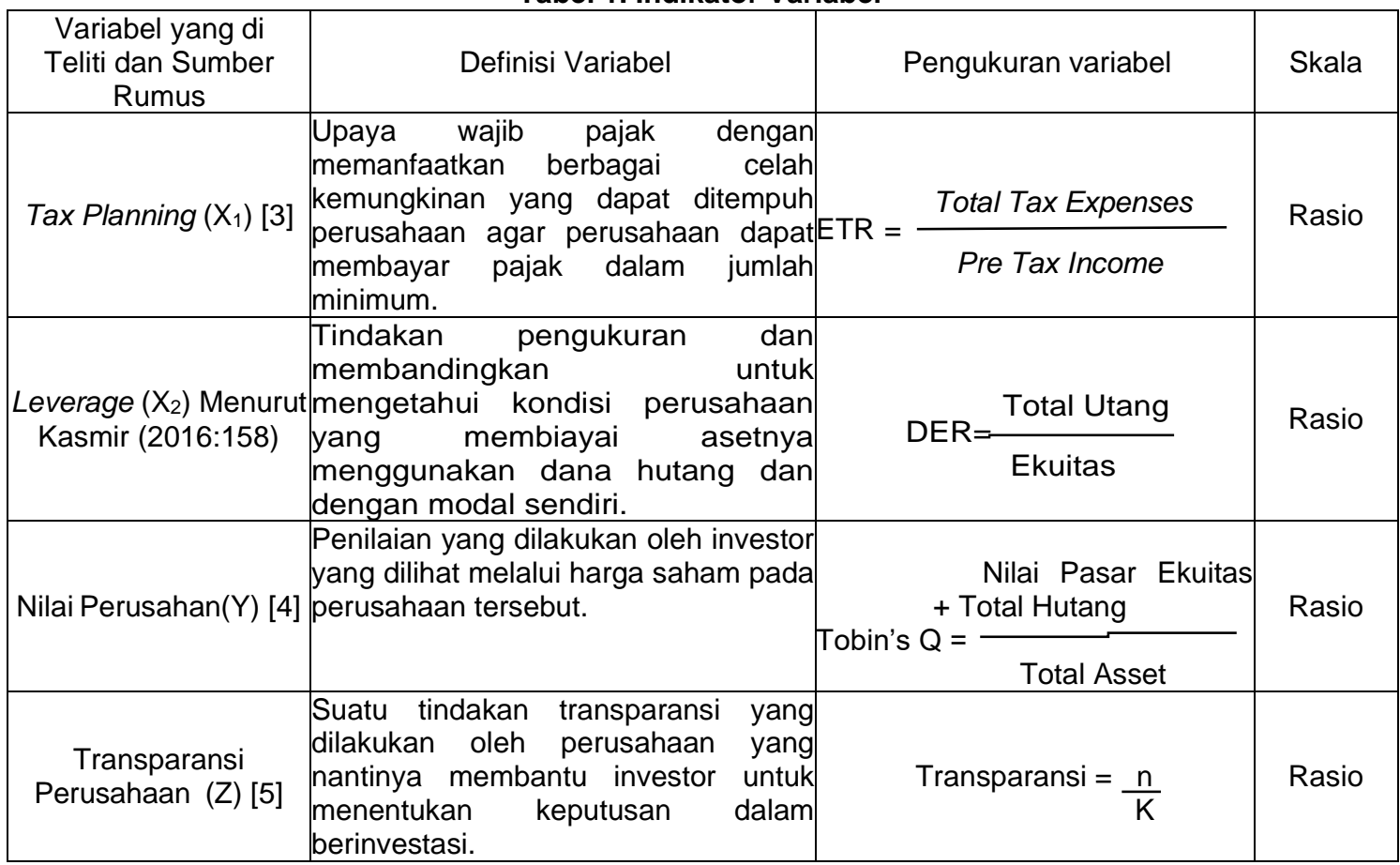

\section{Sampel}

Penelitian ini menggunakan metode purposive sampling yaitu pemilihan sampel secara tidak acak yang informasinya diperoleh menggunakan pertimbangan tertentu umumnya disesuaikan dengan tujuan penelitian. Dengan metode tersebut, sampel dipilih berdasarkan karakteristik yang akan ditentukan. Adapun kriteria pemilihan sampel adalah sebagai berikut :

1. Perusahaan properti dan real estate yang terdaftar di Bursa Efek Indonesia (BEl).

2. Perusahaan properti dan real estate yang menerbitkan laporan keuangan secara lengkap selama periode penelitian tahun 2016-2020.

3. Perusahaan properti dan real estate yang tidak mengalami kerugian selama periode penelitian tahun 2016-2020.

\section{HASIL DAN PEMBAHASAN}

\section{Hasil Uji Statistik Desekriptif}

Tabel 3.1 Statistik Deskriptif

\begin{tabular}{ccccccc}
\hline \hline & NP & TP & $L$ & TPZ & TPZ_TP & TPZ_L \\
\hline \hline Mean & 0.554595 & 0.065005 & 0.679083 & 0.231625 & 0.014975 & 0.151472 \\
Median & 0.632650 & 0.033500 & 0.580150 & 0.205900 & 0.010000 & 0.132400 \\
Maximum & 0.895100 & 0.504300 & 1.676400 & 0.411800 & 0.067700 & 0.466000 \\
Minimum & 0.256500 & 0.004400 & 0.034000 & 0.117600 & 0.001200 & 0.005000 \\
Std. Dev. & 0.156488 & 0.087431 & 0.427338 & 0.093807 & 0.014331 & 0.108468 \\
Observations & 60 & 60 & 60 & 60 & 60 & 60
\end{tabular}

Berdasarkan tabel uji statistik deskriptif di atas, dapat dijelaskan sebagai berikut:

1. Berdasarkan tabel, dari 60 data penelitian nilai NP terkecil (minimum) adalah 0.256500 dan nilai terbesar (maximum) adalah 0.895100 . Nilai median NP dari 60 data adalah 0.632650 dan nilai rata-rata (mean) nya adalah 0.554595 . 
2. Berdasarkan tabel diatas, menujukkan nilai TP terkecil (minimum) adalah 0.004400 dan nilai terbesar (maximum) adalah 0.504300 . Nilai median TP dari 60 data penelitian adalah 0.033500 , dengan nilai rata-rata (mean) adalah 0.065005 .

3. Berdasarkan tabel, dari 60 data penelitian nilai Leverage terkecil (minimum) adalah 0.03400 dan nilai terbesar (maximum) adalah 1.676400. Nilai median Leverage dari 60 data penelitian adalah 0.580150 , dengan nilai rata-rata (mean) adalah 0.679083 .

4. Berdasarkan tabel, dari 60 data penelitian nilai TPZ terkecil (minimum) adalah 0.117600 dan nilai terbesar (maximum) adalah 0.411800 . Nilai median TPZ dari 60 data adalah 0.205900 dan nilai rata-rata (mean) nya adalah 0.231625 .

5. Berdasarkan tabel, dari 60 data penelitian nilai TPZ_TP terkecil (minimum) adalah 0.001200 dan nilai terbesar (maximum) adalah 0.067700 . Nilai median TPZ_TP dari 60 data adalah 0.010000 dan nilai rata-rata (mean) nya adalah 0.014975 .

6. Berdasarkan tabel, dari 60 data penelitian nilai TPZ_L terkecil (minimum) adalah 0.005000 dan nilai terbesar (maximum) adalah 0.466000 . Nilai median TPZ_L dari 60 data adalah 0.132400 dan nilai rata-rata (mean) nya adalah 0.151472 .

\section{Pemilihan Model Regresi Data Panel}

A. Uji Chow

Tabel 3.2 Hasil Uji Chow

\begin{tabular}{lrrr}
\hline \hline Effects Test & Statistic & d.f. & Prob. \\
\hline \hline Cross-section F & 136.715551 & $(11,44)$ & 0.0000 \\
Cross-section Chi-square & 213.626767 & 11 & 0.0000 \\
\hline \hline
\end{tabular}

Berdasarkan hasil Uji Chow pada tabel diatas menunjukkan bahwa nilai probabilitas Cross section $F<$ nilai signifikansi $(0.0000<0,05)$, maka artinya Ho ditolak dan $\mathrm{H} 1$ diterima. Oleh karena itu, model estimasi berdasarkan hasil uji chow adalah fixed effect.

B. Uji Hausman

Tabel 3.3 Hasil Uji Hausman Pertama dan Kedua

\begin{tabular}{lccc}
\hline \hline Test Summary & $\begin{array}{l}\text { Chi-Sq. } \\
\text { Statistic }\end{array}$ & Chi-Sq. d.f. & Prob. \\
\hline \hline Cross-section random & 0.617577 & 3 & 0.8924 \\
\hline \hline & & & \\
\hline Test Summary & $\begin{array}{l}\text { Chi-Sq. } \\
\text { Statistic }\end{array}$ & Chi-Sq. d.f. & Prob. \\
\hline \hline Cross-section random & 2.060731 & 3 & 0.5599 \\
\hline \hline
\end{tabular}

Berdasarkan dari tabel diatas hasil uji hausman pertama terlihat bahwa nilai Probability (cross section random) sebesar 0,8924 $>0,05$. Sedangkan hasil dari uji hausman kedua terlihat bahwa nilai Probability (cross section random) sebesar 0,5599 >0,05. Berdasarkan hasil uji hausman pertama dan kedua yang terpilih adalah random effect model.

\section{Uji Langrange Multiplier (LM)}

Tabel 3.4 Hasil Uji Langrange Multiplier

\begin{tabular}{lccc}
\hline \multicolumn{1}{c}{ Test } & Statistic & d.f. & Prob. \\
\hline \hline Breusch-Pagan LM & 100.0759 & 66 & 0.0043 \\
Pesaran scaled LM & 1.921463 & & 0.0547 \\
Pesaran CD & 2.387483 & & 0.0170 \\
\hline \hline
\end{tabular}


Berdasarkan hasil uji langrange multiplier pada tabel diatas menunjukkan nilai Probabilitas breusch-pagan < nilai signifikansi $(\alpha=0,05)$, artinya estimasi model regresi yang paling baik adalah random effect model.

\section{Hasil Uji Asumsi Klasik}

1. Uji Normalitas

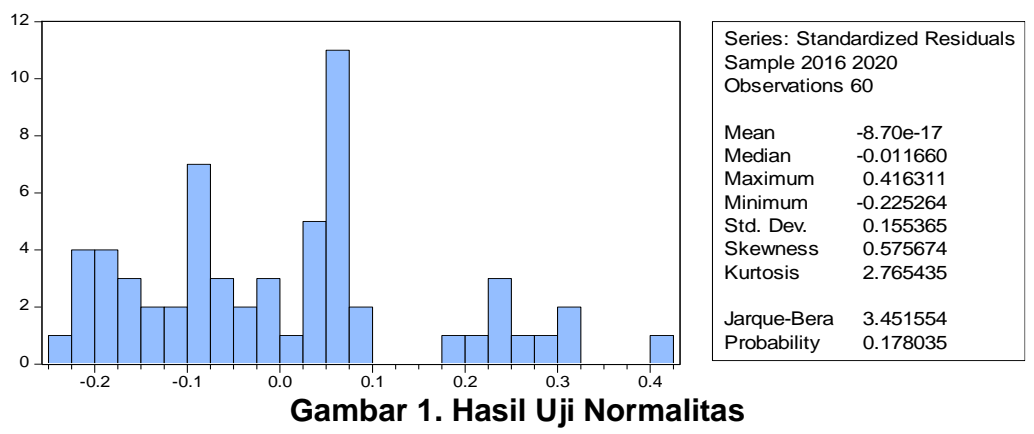

Pada gambar 1. hasil Uji Normalitas dapat disimpulkan model pada penelitian ini berdistribusi normal, karena nilai probability 0,178035 $>0,05$ dan dapat dilanjutkan ke pengujian berikutnya.

2. Uji Multikolinieritas

\begin{tabular}{crccc} 
& \multicolumn{3}{c}{ Tabel 3.5 Hasil Uji Multikolinieritas } \\
& TP & L & TPZ_TP & TPZ_L \\
\hline \hline TP & 1.000000 & 0.054629 & 0.848345 & -0.028909 \\
L & 0.054629 & 1.000000 & 0.059838 & 0.854751 \\
TPZ_TP & 0.848345 & 0.059838 & 1.000000 & 0.036978 \\
TPZ_L & -0.028909 & 0.854751 & 0.036978 & 1.000000
\end{tabular}

Berdasarkan tabel hasil uji multikolinearitas diatas, masing-masing variabel memiliki nilai koefisien korelasinya $<0,90$. Maka dapat disimpulkan bahwa setiap variabel tidak memiliki gejala multikolinearitas.

3. Uji Heterkedastisitas

Tabel 3.6 Hasil Uji Heterokedastisitas

\begin{tabular}{crrrr}
\hline \hline Variable & Coefficient & Std. Error & t-Statistic & Prob. \\
\hline \hline C & 0.188995 & 0.048219 & 3.919525 & 0.0003 \\
NLOGTP & 0.013236 & 0.011239 & 1.177713 & 0.2454 \\
NLOGLV & -0.067033 & 0.036579 & -1.832529 & 0.0738 \\
NLOGZ_TP & -0.008916 & 0.011408 & -0.781509 & 0.4388 \\
NLOGTPZ_L & 0.084721 & 0.035604 & 2.379536 & 0.0218 \\
\hline \hline
\end{tabular}

Berdasarkan hasil uji heterokedastisitas, $p$-value dari keduanya yaitu kurang dari 0,05 yang berarti terjadi gejala heteroskedastisitas, namun dalam kasus ini dapat diabaikan. Uji ini hanya akan akurat jika Anda lakukan untuk data cross section, maka data panel memiliki ciri-ciri yang lebih dekat ke data cross section dari pada data time series. Sehingga model REM diasumsikan terbebas dari gejala heteroskedastisitas.

4. Uji Autokorelasi

Tabel 3.7 Hasil Uji Autokorelasi

$\begin{array}{llll}\text { R-squared } & 0.618010 & \text { Mean dependent var } & 0.038112 \\ \text { Adjusted R-squared } & 0.590229 & \text { S.D. dependent var } & 0.042988 \\ \text { S.E. of regression } & 0.027518 & \text { Sum squared resid } & 0.041648 \\ \text { F-statistic } & 22.24575 & \text { Durbin-Watson stat } & 1.326911 \\ \text { Prob(F-statistic) } & 0.000000 & \end{array}$


Berdasarkan hasil uji autokorelasi pada tabel diatas menunjukan bahwa nilai dari DurbinWatson (DW) sebesar 1,326911 atau berada diantara $-2<1,326911<2$, yang berarti model regresi tidak mengalami autokorelasi dan model regresi ini layak untuk digunakan.

\section{Uji Hipotesis}

1. Uji Djusted R2 (Koefisien Determinasi)

Tabel 3.8 Hasil Uji Koefisien Determinasi

\begin{tabular}{llll}
\hline \hline & & & \\
R-squared & 0.618010 & Mean dependent var & 0.038112 \\
Adjusted R-squared & 0.590229 & S.D. dependent var & 0.042988 \\
S.E. of regression & 0.027518 & Sum squared resid & 0.041648 \\
F-statistic & 22.24575 & Durbin-Watson stat & 1.326911 \\
Prob(F-statistic) & 0.000000 & & \\
& & & \\
\hline \hline
\end{tabular}

Pada tabel hasil uji R-square setelah moderasi di atas diketahui bahwa nilai koefisien determinasi untuk model regresi antara variabel independen dan dependen pada adjusted Rsquare adalah 0,590229 , ini berarti bahwa variasi variabel independen dapat mempengaruhi sebesar 59,02\% pada variabel dependen (nilai perusahaan). Sedangkan 40,98\% nilai perusahaan dipengaruhi oleh variasi variabel lain yang tidak dimasukkan dalam penelitian ini.

2. Uji Parsial (Uji T)

Tabel 3.9 Hasil Uji Parsial (Uji T)

\begin{tabular}{crrrr}
\hline \hline Variable & Coefficient & Std. Error & t-Statistic & Prob. \\
& & & & \\
\hline \hline C & 0.403579 & 0.056968 & 7.084290 & 0.0000 \\
TP & 0.269076 & 0.127114 & 2.116808 & 0.0388 \\
L_ & 0.044217 & 0.074712 & 0.591824 & 0.5564 \\
TPZ_TP & -1.570495 & 0.752793 & -2.086223 & 0.0416 \\
& 0.838547 & 0.324610 & 2.583246 & 0.0125 \\
\hline \hline
\end{tabular}

1. Pengaruh Tax Planning terhadap Nilai Perusahaan

Hasil pengujian analisis regresi data panel diatas menunjukkan probabilitas tax planning < nilai signifikansi $(0.0388<0,05)$ dan nilai thitung > ttabel $(2.116808>2.00324)$ maka $\mathrm{H} 1$ ditolak dan $\mathrm{H} 2$ diterima. Sehingga dapat disimpulkan bahwa tax planning berpengaruh signifikan terhadap nilai perusahaan.

2. Pengaruh Leverage terhadap Nilai Perusahaan

Hasil pengujian analisis regresi data panel diatas menunjukkan probabilitas leverage $>$ nilai signifikansi $(0.5564>0,05)$ dan nilai thitung < ttabel $(0.591824<2.00324)$ maka H1 diterima dan H2 ditolak. Sehingga dapat disimpulkan bahwa leverage tidak berpengaruh signifikan terhadap nilai perusahaan.

3. Pengaruh Tax Planning terhadap Nilai Perusahaan dimoderasi oleh Transparansi Perusahaan

Hasil pengujian analisis regresi data panel diatas menunjukkan probabilitas tax planning yang dimoderasi dengan transparansi perusahaan $<$ nilai signifikansi $(0.0416<0,05)$ dan nilai thitung $>$ ttabel (-2.086223 > 2.00324) maka H1 ditolak dan H2 diterima. Sehingga dapat disimpulkan bahwa tax planning yang dimoderasi dengan transparansi perusahaan memperkuat secara negatif terhadap nilai perusahaan. 
4. Pengaruh Leverage terhadap Nilai Perusahaan dimoderasi oleh Transparansi Perusahaan

Hasil pengujian analisis regresi data panel diatas menunjukkan probabilitas leverage yang dimoderasi dengan transparansi perusahaan $<$ nilai signifikansi $(0.0125<0,05)$ dan nilai thitung $>$ ttabel $(2.583246>2.00324)$ maka H1 ditolak dan H2 diterima. Sehingga dapat disimpulkan bahwa leverage yang dimoderasi dengan transparansi perusahaan memperkuat pengaruh signifikan terhadap nilai perusahaan.

3. Uji Simultan (Uji F)

Tabel 3.10 Hasil Uji Simultan (Uji F)

\begin{tabular}{llll}
\hline \hline & & & \\
R-squared & 0.618010 & Mean dependent var & 0.038112 \\
Adjusted R-squared & 0.590229 & S.D. dependent var & 0.042988 \\
S.E. of regression & 0.027518 & Sum squared resid & 0.041648 \\
F-statistic & 22.24575 & Durbin-Watson stat & 1.326911 \\
Prob(F-statistic) & 0.000000 & & \\
& & & \\
\hline
\end{tabular}

Berdasarkan hasil uji $\mathrm{F}$ hitung pada tabel di atas, nilai $\mathrm{F}$ hitung sebesar 22.24575 dan nilai signifikansi 0,000000 . $F$ tabel dapat dilihat pada tabel statistik pada tingkat signifikansi 0.05 dengan df-1 (jumlah variabel-1) atau 4- 1=3 (N1) dan df 3 (n-k-1) atau 60-3-1=56 (N2) (n adalah jumlah data dan $\mathrm{k}$ adalah jumlah variabel independen). Hasil diperoleh untuk $\mathrm{F}$ tabel sebesar 2,77 , sehingga $\mathrm{F}$ hitung $>\mathrm{F}$ tabel $(22.24575>2,77)$ dan nilai probability $(F$-statistic $)<$ nilai signifikansi $(0.000000<0.05)$. Maka secara bersama-sama (simultan) terdapat pengaruh signifikan antara tax planning dan leverage terhadap nilai perusahaan dengan transparansi perusahaan sebagai variabel moderasi pada perusahaan properti dan real estate di Bursa Efek Indonesia periode 2016-2020.

\section{Analisis Regresi Moderasi}

Tabel 3.11 Hasil Uji Random Effect model

\begin{tabular}{crrrr}
\hline \hline Variable & Coefficient & Std. Error & t-Statistic & Prob. \\
& & & & \\
\hline \hline C & 0.403579 & 0.056968 & 7.084290 & 0.0000 \\
TP & 0.269076 & 0.127114 & 2.116808 & 0.0388 \\
L & 0.044217 & 0.074712 & 0.591824 & 0.5564 \\
TPZ_TP & -1.570495 & 0.752793 & -2.086223 & 0.0416 \\
TPZ_L & 0.838547 & 0.324610 & 2.583246 & 0.0125 \\
& & & & \\
\hline \hline
\end{tabular}

Berdasarkan tabel diatas, maka diperoleh persamaan model regresi antara variabel dependen (Nilai Perusahaan), variabel independen (Tax Planning, Leverage) dan variabel moderating (Transparansi Perusahaan) sebagai berikut :

$N P=0.403579+0.269076 T P+0.044217 L-1.570495 T P Z^{*} T P+0.838547 T P Z^{*} L$

1. Konstanta sebesar 0.403579 menunjukkan bahwa jika variabel independen bernilai sama dengan nol, maka Nilai Perusahaan adalah sebesar 0.403579.

2. Koefisien Tax Planning (X1) sebesar 0.269076 . Hal ini menunjukkan bahwa setiap kenaikan hasil Tax Planning 1\% dengan catatan bahwa variabel lain dianggap konstan, maka akan meningkatkan Tax Planning sebesar 0.269076.

3. Koefisien Leverage (X2) sebesar 0.044217 dan bertanda positif, artinya jika Laverage (X2) naik $1 \%$ dengan mengasumsikan bahwa variabel lain tetap, maka Nilai Perusahaan akan mengalami kenaikan sebesar 0.044217 .

4. Koefisien Tax Planning yang dimoderasi dengan Transparansi Perusahaan (TP*TPZ) sebesar 1.570495 dan bertanda negatif, artinya jika Tax Planning yang dimoderasi dengan Transparansi Perusahaan (TP*TPZ) naik $1 \%$ dengan mengasumsikan bahwa variabel lain tetap, maka Nilai Perusahaan akan mengalami penurunan sebesar 1.570495. 
5. Koefisien Leverage yang dimoderasi dengan Transparansi Perusahaan ( $\left.L^{*} T P Z\right)$ sebesar 1.326866 dan bertanda positif, artinya jika Leverage yang dimoderasi dengan Transparansi Perusahaan $\left(L^{*} T P Z\right)$ naik $1 \%$ dengan mengasumsikan bahwa variabel lain tetap, maka Nilai Perusahaan akan mengalami kenaikan sebesar 1.326866.

\section{Pembahasan}

\section{Pengaruh Tax Planning terhadap Nilai perusahaan}

Hasil penelitian ini mendukung penelitian yang menyatakan bahwa tax planning berpengaruh terhadap nilai perusahaan. Hal ini karena perencanaan pajak dapat meminimalkan biaya pajak yang dibayarkan sehingga dapat meningkatkan nilai perusahaan. Peminimalan biaya pajak yang dibayarkan menyebabkan keuntungan yang diperoleh lebih besar sehingga dividen yang dibayarkan semakin tinggi kepada investor. Dividen yang tinggi menyebabkan investor menanamkan investasinya dan memicu investasi baru, sehingga harga saham meningkat diikuti dengan meningkatnya nilai perusahaan.

\section{Pengaruh leverage terhadap nilai Perusahaan}

Hasil penelitian ini mendukung penelitian yang menyatakan bahwa leverage tidak berpengaruh terhadap nilai perusahaan. Hal ini karena perusahaan yang memiliki hutang tinggi akan berdampak pada kepercayaan public terhadap perusahaan. Penggunaan hutang yang tidak sesuai dengan porsi akan membawa dampak negatif terhadap perusahaan. Salah satu dampak negatif tersebut yaitu financial distress, dimana perusahaan mengalami financial distress itu akan berpengaruh terhadap pembagian deviden yang akan diterima investor. Penurunan dividen tersebut mengurangai kemakmuran para pemegang saham sehingga nilai perusahaan juga akan ikut menurun.

\section{Pengaruh Tax Planning dan Leverage secara Simultan terhadap Nilai Perusahaan}

Hasil penelitian ini diperoleh menjelaskan bahwa variabel tax planning dan leverage secara simultan berpengaruh signifikan terhadap nilai perusahaan. Hasil penelitian ini sama dengan penelitian sebelumnya, penelitian lain menunjukkan bahwa variable DER, EPS, ROE, dan DR secara simultan signifikan pengaruhnya terhadap harga saham perusahaan food and beverage periode tahun 2009-2012.

\section{Pengaruh Tax Planning yang dimoderasi Transparansi Perusahaan terhadap Nilai Perusahaan}

Hasil penelitian ini mendukung penelitian yang menyatakan bahwa transparansi berpengaruh serta mampu memoderasi penghindaran pajak terhadap nilai perusahaan. Hal ini karena kian banyak informasi yang diungkapkan oleh manajemen pada laporan keuangan atau tahunannya, maka investor maupun pemilik perusahaan dapat mengetahui bagaimana kondisi perusahaan sebenarnya. Selain itu, kemudahan dalam akses informasi tersebut juga menjadi salah satu indicator dari transparansi perusahaandalam menyampaikan informasi kepada pihak di luar perusahaan. Dengan adanya transparansi ini, peluang-peluang dari manajemen untuk melakukan perencanaan pajak yang bersifat atau memiliki niatan menguntungkan pribadi akan dapat dikurangi.

\section{Pengaruh Leverage yang dimoderasi Transparansi Perusahaan terhadap Nilai Perusahaan}

Hasil penelitian ini mendukung penelitian terdahulun yang menyatakan bahwa profitabilitas berpengaruh positif terhadap nilai perusahaan. Hal ini karena Perusahaan dalam mendanai aktivanya cenderung menggunakan modal sendiri (internal financing) yang berasal dari laba ditahan dan modal saham daripada menggunakan hutang. Kecukupan dana yang dimiliki perusahaan untuk membiayai aktivanya yang diperoleh dari modal sendiri membuat perusahaan mengurangi proporsi hutangnya. Penggunaan hutang yang berlebihan akan mengurangi manfaat yang diterima atas penggunaan hutang karena manfaat yang diterima tidak sebanding dengan biayai yang ditimbulkan, sehingga proporsi hutang yang rendah dapat meningkatkan nilai perusahaan dan sebaliknya peningkatan hutang dapat menurunkan nilai perusahaan. 


\section{KESIMPULAN}

Berdasarkan data yang telah dikumpulkan terhadap 12 sampel perusahaan dalam periode 2016-2020 dengan pengujian menggunakan Eviews 9, maka diperoleh kesimpulan sebagai berikut :

1. Berdasarkan hasil pengujian yang dilakukan pada penelitian ini menyatakan bahwa Tax Planning berpengaruh dan signifikan terhadap Nilai Perusahaan pada perusahaan property dan real estate pada periode 2016-2020.

2. Berdasarkan hasil pengujian yang dilakukan pada penelitian ini menyatakan bahwa leverage tidak berpengaruh dan signifikan terhadap nilai perusahaan perusahaan property dan real estate pada periode 2016-2020.

3. Berdasarkan hasil pengujian yang dilakukan pada penelitian ini menyatakan bahwa Tax Planning dan Leverage berpengaruh dan signifikan terhadap Nilai Perusahaan perusahaan property dan real estate pada periode 2016-2020.

4. Berdasarkan hasil pengujian yang dilakukan pada penelitian ini meyatakan bahwa tax planning yang dimoderasi transparansi perusahaan, berpengaruh negatif dan signifikan terhadap nilai perusahaan perusahaan property dan real estate pada periode 2016-2020.

5. Berdasarkan hasil pengujian yang dilakukan pada penelitian ini menyatakan bahwa leverage yang dimoderasi transparansi perusahaan berpengaruh positif dan signifikan terhadap nilai perusahaan perusahaan property dan real estate pada periode 2016-2020.

\section{Keterbatasan}

1. Variabel independen yang digunakan dalam penelitian ini hanya 2 variabel yaitu tax planning dan leverage untuk mempengaruhi nilai perusahaan. Sementara masih banyak variabel lain yang dapat mempengaruhi nilai perusahaan antara lain yaitu profitabilitas, struktur modal, kebijakan deviden dan lain-lain.

2. Penelitian ini menggunakan sampel penelitian yang terbatas yaitu hanya pada perusahaan properti dan real estate yang terdapat di Bursa Efek Indonesia

3. Sampel yang digunakan dalam penelitian ini terbatas yaitu sebanyak 15 perusahaan properti dan real estate yang terdaftar di Bursa Efek Indonesia.

\section{UCAPAN TERIMAKASIH}

1. Bapak Hari Stiawan, S.E., M.AK. selaku dosen pembimbing yang telah sabar dan bijak membimbing, memberi dukungan, dan membantu saya dalam mengerjakan skripsi ini hingga selesai.

2. Kedua orang tua yang senantiasa memberikan dukungan baik materil maupun do'a dan kasih sayang

\section{REFERENCES}

[1] I. A. Arief, "Kasus Korupsi Meikarta, Nilai Pasar Lippo Cs Turun Rp 1,43 T," 21 oktober 2018. [Online]. Available: https://www.cnbcindonesia.com/market/20181021135404-17-38331/kasuskorupsi-meikarta-nilai-pasar-lippo-cs-turun-rp-143-t.

[2] Prasiwi and W. Kristantina, "Pengaruh Penghindaran Pajak Terhadap Nilai Perusahaan: Transparansi Sebagai Variabel Pemoderasi," Skripsi Universitas Diponegoro, 2015.

[3] H. Herawati and D. Ekawati, Pengaruh Perencanaan Pajak Terhadap Nilai Perusahaan, 2016.

[4] D. Nursari and Sukarmanto, "Pengaruh Profitabilitas, Leverage, dan Kepemilikan Institusional Terhadap Tax Avoidance," Prosiding Akuntansi Universitas Islam Bandung, vol. 3, no. 2, 2017.

[5] A. Novarianto and S. Dwimulyanti, "Pengaruh Penghindaran Pajak, Leverage, Profitabilitas Terhadap nilai Perusahaan dengan Transparansi Perusahaan sebagai Variabel Moderasi," Prosiding Seminar Nasional Pakar, 2019.

[6] I. B. G. P. Pradnyana and N. Noviari, "PENGARUH PERENCANAAN PAJAK TERHADAP NILAI PERUSAHAAN DENGAN TRANSPARANSI PERUSAHAAN SEBAGAI VARIABEL MODERASI," EJurnal Akuntansi Universitas Udayana, vol. 18, no. 2, pp. 1398-1425, Februari 2017.

[7] I. D. Partha, "Pengaruh Penghindaran Pajak Pada Nilai Perusahaan dengan Transparansi Perusahaan Sebagai Variabel Pemoderasi," Jurnal Akuntansi Universitas Udayana, vol. 14, no. 30, pp. 2336-2362, 2016. 
[8] I. Ghozali, Aplikasi Analisis Multivariate dengan Program IBM SPSS 23, Semarang: Badan Penerbit Universitas Diponegoro, 2016.

[9] "Saham Properti Berguguran, Kinerja Semester I Mengecewakan," cnbcindonesia.com, 2018.

[10] Z. Akbar, W. Irawati, R. Wulandari and H. Barli, "Analisis Profitabilitas, Leverage, Pertumbuhan Penjualan dan Kepemilikan Keluarga Terhadap Penghindaran Pajak," Akuntansi, vol. 7(2), pp. 190 199, 2020. 